Aluen, L. A., Pasley, S. M. \& Pierce, M. S. F. (1952). J. gen. Microbiol. 7, $257-267$.

\title{
Conditions affecting the Growth of Bacterium coli on Bile Salts Media. Enumeration of this Organism in Polluted Waters
}

\author{
By L. A. ALleN, SHEIla M. PASLEY AND \\ MARGARET S. F. PIERCE \\ Water Pollution Research Laboratory, Langley Road, Watford
}

SUMMARY: The growth of Bacterium coli on agar media containing bile salts is conditioned by a number of factors. The proportion of total cells able to grow on a medium not containing bile salts rapidly declines at temperatures of incubation above $43^{\circ}$. On a medium containing bile salts and lactose a distinctly inhibitory effect is observed at $37^{\circ}$; with most strains this effect is still more pronounced at $44^{\circ}$. Some brands of bile salts are appreciably more inhibitory than others. Inclusion of phosphate in a bile salts medium introduces a markedly inhibitory factor, the severity of which varies with the strain of organism; some strains are virtually unable to grow on such a medium.

When a culture of Bact. coli is suspended in water containing only small concentrations of inorganic salts an increasing proportion of the population becomes attenuated so that the cells are unable to grow on bile salts lactose agar at $\mathbf{4 4 ^ { \circ }}$. An occasional strain may also exhibit sensitiveness to the presence of neutral red. This attenuating effect may be largely decreased if, before the inoculum is mixed with the bile salts and agar, it is subjected to a short period of incubation with lactose broth. This treatment has been made the basis of a technique for obtaining a colony count of Bact. coli which is applicable to polluted waters.

Several workers (cf. Wilson, Twigg, Wright, Hendry, Cowell \& Mair, 1935; Clegg \& Sherwood, 1939; Sherwood \& Clegg, 1942; Batty-Smith, 1942; Allen, Brooks \& Williams, 1949), have found ability to ferment bile salts lactose broth at $44^{\circ}$ a reasonably specific test for Bacterium coli type $I$, and a method of enumeration based on this test was outlined by the Ministry of Health (1939). Disadvantages of the method are the large quantity of medium required and the large error involved in the computation of the most probable number. Thus Halvorson \& Ziegler (1933) calculated that, with five tubes of medium to each dilution, the count obtained will be between $70 \%$ below and $260 \%$ above the true value.

Enumeration of this organism provides a simple method of following the effect of different treatments of sewage on the numbers of faecal bacteria discharged into a river and of the rate at which these numbers decrease as the organisms are carried downstream. A colony count of Bact. coli would introduce into sanitary surveys of this character a welcome improvement in accuracy. Clegg \& Sherwood (1947) introduced a roll-tube method of counting faecal coli in shellfish in which inocula were mixed with a modified MacConkey agar and the tubes were incubated at $44^{\circ}$. Preliminary tests showed, however, that the ability of cells of Bact. coli to form colonies on bile salts lactose agar 


\section{L. A. Allen, Sheila M. Pasley and Margaret S. F. Pierce}

was profoundly affected by a number of conditions. These conditions were investigated before the results were embodied in the method of enumeration finally adopted.

\section{EXPERIMENTAL}

After various methods of preparing films of agar media in tubes and bottles had been tried a technique similar to that described by Tai \& van Heyningen (1950) was adopted. A chuck, rotating horizontally, was mounted on the shaft of a variable speed motor so that a bottle containing molten nutrient medium and an inoculum could be rotated at a speed of several hundred revolutions/min. For inocula of $1 \mathrm{ml}$. small glass bottles of the type described by Proom \& Hemmons (1949) with a capacity of $30 \mathrm{ml}$. were used. For a larger size of inoculum bottles measuring about $4 \mathrm{~cm}$. diameter and $15 \mathrm{~cm}$. in length from base to shoulder were found suitable. Details as to the kind and quantity of medium and size of inoculum are given later but, in general, the inoculum was added to a bottle containing the liquid medium at a temperature of about $48^{\circ}$. The bottle was gently shaken to mix the contents and immediately placed in the chuck and rotated. The chuck and bottle were arranged to project over a sink so that, while rotating, the bottle could be cooled with a jet of cold water. Four similar machines were arranged side by side. Water cooling was found to be preferable to air cooling in that it ensured a firm adherent film after the bottle had been rotated for a comparatively short time (for the small bottles about $30 \mathrm{sec}$. sufficed). With air cooling several minutes are required on a warm day and if the bottles are removed from the chuck a little too soon the agar film develops slight wrinkles and usually collapses before or during incubation.

\section{Comparative counts in bottles and Petri dishes and with different brands of agar}

Comparative trials with Petri dishes and bottles, and with New Zealand and Japanese agars, showed that neither the kind of agar nor the type of container made any significant difference to the counts. Since, owing to the firmer gel it forms, there are advantages in using New Zealand agar for bottle counts, this material was used in the subsequent experiments. In most experiments bottle counts were averages of three or four determinations.

\section{Effect of temperature of incubation on the count}

The effect of temperature of incubation on the proportion of the total population of cells able to proliferate was tested on nutrient agar (without bile salts). Six strains of Bact. coli were grown in nutrient broth at $37^{\circ}$. After incubation for $6 \mathrm{hr}$., and again after 3 days, replicate counts were made in bottles of nutrient agar at $37,39,40,41,42,43,44$ and $45^{\circ}$. Counts, expressed as percentages of the corresponding counts at $37^{\circ}$, are shown graphically in Fig. 1 (only three of the strains were tested at temperatures up to $41^{\circ}$ ).

It is clear that a temperature of $44^{\circ}$ is critical for this organism (cf. Clegg \& 
Sherwood, 1939; 'Taylor, 1945), and it is important that the temperature of the water-bath should be accurately controlled. The average of the twelve counts at $44^{\circ}$ was $74 \%$, and of the eleven counts at $43^{\circ}, 90 \%$ of the count at $37^{\circ}$.

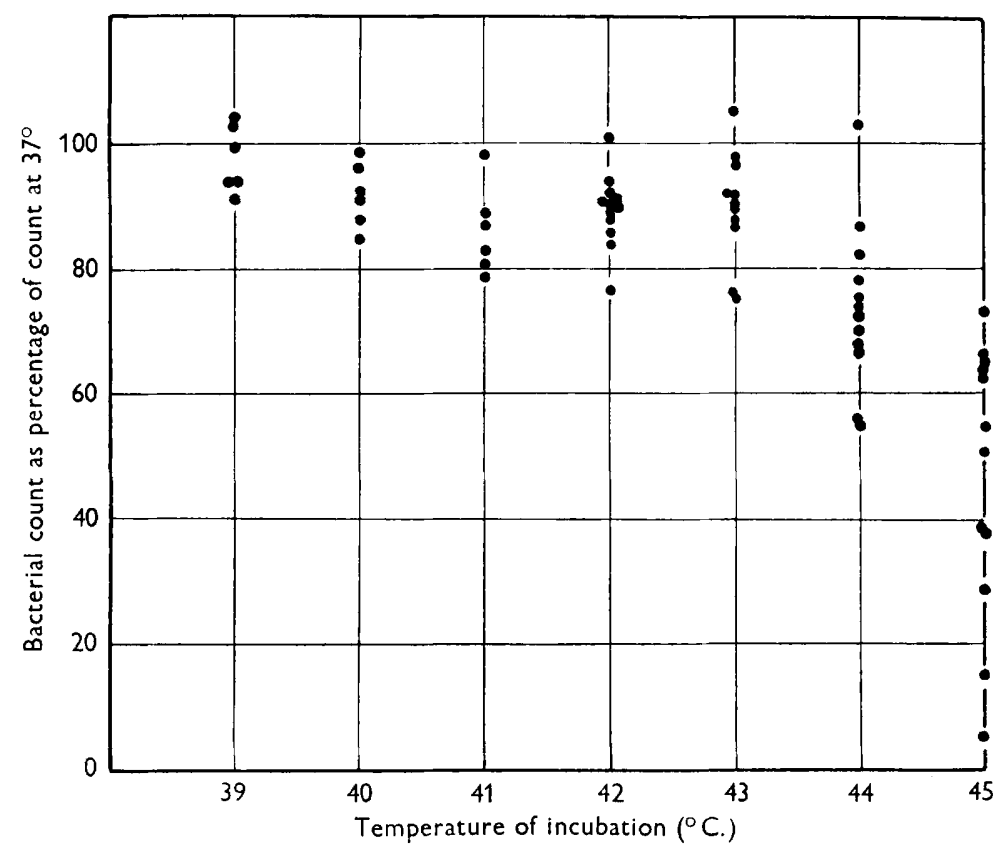

Fig. 1. Colony counts of broth cultures (when $6 \mathrm{hr}$. and when 3 days old) of six strains of Bact. coli at different temperatures of incubation (each count expressed as percentage of count of the same culture at $37^{\circ}$ ).

\section{Proportion of cells able to grow on bile salts-lactose agar at $37^{\circ}$ and at $44^{\circ}$}

Colony counts, at both 37 and $44^{\circ}$, on nutrient agar and on bile salts lactose agar prepared from two different recipes (given below) were made of broth cultures of six strains of Bact. coli (Table 1). The inhibiting action of the bile salts media, which was appreciable at $37^{\circ}$, was still more marked at $44^{\circ}$. Medium D, containing phosphate as well as bile salts, was inferior to medium $\mathbf{A}$ and at the higher temperature two strains were scarcely able to grow at all. Further tests were made with this medium in which different concentrations of bile salts were tried $(0 \cdot 5,1 \cdot 0,1 \cdot 5 \mathrm{~g} . / 1$.$) , but no difference was observed in the$ inhibitory effect.

\section{Comparison of different bile salts media}

It is evident from the literature that the count of Bact. coli will be affected by the kind and concentration of bile salts, though it is doubtful whether this is generally appreciated. Leifson (1935) found that of the bile acids he tested deoxycholic acid exerted the strongest effect on bacterial growth, and that a number of substances exerted a strongly inhibitory action on coli-aerogenes bacteria when incorporated in a sodium deoxycholate medium. These substances included sodium chloride, acetates, propionates, butyrates and citrates, 
Table 1. Comparative colony counts of Bact. coli on nutrient agar at $37^{\circ}$ and on bile salts lactose agar at $37^{\circ}$ and at $44^{\circ}$

\begin{tabular}{|c|c|c|c|c|c|c|}
\hline & & & & Bile salts & actose agar & \\
\hline & & Nutrient & At & $37^{\circ}$ & & $44^{\circ}$ \\
\hline Strain & Age & $27^{\circ}$ & $\begin{array}{r}\text { Medium A } \\
\text { Cor }\end{array}$ & $\begin{array}{l}\text { Medium D } \\
\text { nt (millions }\end{array}$ & $\begin{array}{l}\text { Medium A } \\
\text { ml.) }\end{array}$ & Medium D \\
\hline H 7 & $\begin{array}{l}6 \mathrm{hr} . \\
5 \text { days }\end{array}$ & $\begin{array}{c}332 \\
91\end{array}$ & $\begin{array}{r}287 \\
51\end{array}$ & $\begin{array}{r}259 \\
37\end{array}$ & $\begin{array}{r}215 \\
30\end{array}$ & $\begin{array}{c}210 \\
20\end{array}$ \\
\hline H 1 & $\begin{array}{l}6 \mathrm{hr} . \\
5 \text { days }\end{array}$ & $\begin{array}{r}250 \\
92\end{array}$ & $\begin{array}{r}165 \\
75\end{array}$ & $\begin{array}{r}197 \\
67\end{array}$ & $\begin{array}{r}156 \\
73\end{array}$ & $\begin{array}{r}104 \\
20\end{array}$ \\
\hline H 8 & $\begin{array}{l}6 \mathrm{hr} . \\
5 \text { days }\end{array}$ & $\begin{array}{r}241 \\
44\end{array}$ & $\begin{array}{r}163 \\
35\end{array}$ & $\begin{array}{r}165 \\
19\end{array}$ & $\begin{array}{r}118 \\
38\end{array}$ & $\begin{array}{l}* \\
<0 \cdot 1\end{array}$ \\
\hline H 6 & $\begin{array}{l}6 \text { hr. } \\
5 \text { days }\end{array}$ & $\begin{array}{r}235 \\
43\end{array}$ & $\begin{array}{r}175 \\
36\end{array}$ & $\begin{array}{r}145 \\
30\end{array}$ & $\begin{array}{l}69 \\
32\end{array}$ & $\begin{array}{l}50 \\
18\end{array}$ \\
\hline H 0 & $\begin{array}{l}6 \mathrm{hr} . \\
5 \text { days }\end{array}$ & $\begin{array}{r}224 \\
35\end{array}$ & $\begin{array}{r}184 \\
28\end{array}$ & $\begin{array}{r}200 \\
26\end{array}$ & $\begin{array}{r}157 \\
22\end{array}$ & $\begin{array}{r}151 \\
11\end{array}$ \\
\hline H 13 & $\begin{array}{l}6 \mathrm{hr} \text {. } \\
5 \text { days }\end{array}$ & $\begin{array}{l}253 \\
6 \cdot 0\end{array}$ & $\begin{array}{c}185 \\
4 \cdot 8\end{array}$ & $\begin{array}{l}153 \\
0 \cdot 2\end{array}$ & $\begin{array}{r}102 \\
2.9\end{array}$ & $\begin{array}{l}44 \\
0.5\end{array}$ \\
\hline
\end{tabular}

Medium A=Ministry of Health recipe. Medium D=Hajna \& Perry's 'EC' recipe (plus agar and neutral red).

* Counts in triplicate tubes highly inconsistent.

and their inhibitory action was enhanced by the presence of unknown substances in meat infusion and in certain brands of peptone.

Cultures of two strains of Bact. coli in nutrient broth were incubated at $37^{\circ}$, and at intervals comparative counts in bottles at $44^{\circ}$ were made in the following four media:

A: MacConkey agar (Ministry of Health, 1939) of the following composition (g./l.): peptone, 20 g.; sodium taurocholate, 5 g.; lactose, 10 g.; neutral red, $10 \mathrm{ml}$. of $1 \%$ solution.

B : similar to A but containing $\mathbf{5} \mathrm{g}$./l. of a proprietary brand of specially pure bile salts.

C: similar to A but containing $20 \mathrm{~g}$./l. of ox-gall instead of sodium taurocholate.

D: the 'EC' medium prescribed by Hajna \& Perry (1943) made up with agar and containing neutral red as indicator and the same brand of bile salts as B. The composition (g./l.) was as follows: Bacto tryptose, $20 \mathrm{~g}$.; $\mathrm{NaCl}, \mathbf{5}$ g.; $\mathrm{K}_{2} \mathrm{HPO}_{4}$, 4 g.; $\mathrm{KH}_{2} \mathrm{PO}_{4}, 1.5$ g.; bile salts ' $\mathrm{X}$ ', 1.5 g.; neutral red, $5 \mathrm{ml} .1 \%$ solution.

In all media $1 \cdot 5 \%$ New Zealand agar was incorporated.

Results ('Table 2) showed that medium A gave higher counts than B or $\mathbf{C}$. On medium $\mathrm{D}$ counts were much lower than on the other three media and with strain $\mathrm{H} 8$ the effect was so marked that virtually no growth occurred. The concentration of bile salts was less in medium $D(0.15 \%)$ than in medium B $(0.5 \%)$. This substance by itself could not, therefore, have been the main inhibitory agent. 
Inhibitory effect of phosphate in bile salts media

Counts of broth cultures of six strains of Bact. coli were determined when $6 \mathrm{hr}$. old, and again after 6 days, on media $\mathrm{A}$ and $\mathrm{D}$, and on medium $\mathrm{D}$ from which the phosphate was omitted. Results ('Table 3) show that omission of phosphate removed a strongly inhibitory factor from medium $\mathbf{D}$ which now gave higher counts than medium $\mathbf{A}$.

Table 2. Comparative counts of Bact. coli in bottles at $44^{\circ}$ on different bile salts media

$\overbrace{\mathrm{A} \quad \mathrm{B}}^{\overbrace{\mathrm{C}}} \overbrace{\mathrm{D}}^{\text {Bile salts } \overbrace{\mathrm{A}}^{\text {Strain } \mathrm{H}_{1}}}$

\begin{tabular}{|c|c|c|c|c|c|c|c|c|}
\hline \multirow{2}{*}{$\begin{array}{c}\text { Age of } \\
\text { culture } \\
0 \mathrm{hr} .\end{array}$} & \multicolumn{8}{|c|}{ Count (millions/ml.) } \\
\hline & $0 \cdot 70$ & $0 \cdot 44$ & $0 \cdot 69$ & $0 \cdot 44$ & $0 \cdot 28$ & $0 \cdot 072$ & $0 \cdot 126$ & $0^{*}$ \\
\hline $4 \mathrm{hr}$. & 151 & 122 & 119 & 48 & 61 & $16 \cdot 2$ & $32 \cdot 2$ & $\mathbf{0}$ \\
\hline $24 \mathrm{hr}$. & 382 & 204 & 276 & 208 & 140 & $15 \cdot 0$ & $22 \cdot 8$ & $\mathbf{0}$ \\
\hline $48 \mathrm{hr}$. & 306 & 156 & 164 & 78 & 250 & $34 \cdot 2$ & $22 \cdot 0$ & 0 \\
\hline $72 \mathrm{hr}$. & - & 一 & -.. & - & 92 & $7 \cdot 8$ & $10 \cdot 4$ & 0 \\
\hline 4 days & 90 & 44 & 76 & $3 \cdot 6$ & - & - & - & - \\
\hline 5 days & - & 一 & 一 & - & 52 & $18 \cdot 4$ & $20 \cdot 4$ & 0 \\
\hline 6 days & $18 \cdot 8$ & $12 \cdot 0$ & $14 \cdot 6$ & $2 \cdot 9$ & 41 & $2 \cdot 4$ & $18 \cdot 6$ & 0 \\
\hline 7 days & $20 \cdot 4$ & $16 \cdot 4$ & $12 \cdot 8$ & $10 \cdot 0$ & $\ldots$ & - & - & - \\
\hline
\end{tabular}

A = MacConkey agar (Ministry of Health, 1939).

$\mathrm{B}=$ Similar to A but $5 \mathrm{~g}$. proprietary brand of specially pure bile salts/1. instead of $\mathrm{Na}$ taurocholate.

$\mathrm{C}=$ Similar to $\mathrm{A}$ but $20 \mathrm{~g}$. ox-gall/l. instead of $\mathrm{Na}$ taurocholate.

$\mathrm{D}=$ Hajna \& Perry's (1943) 'EC' medium.

* less than $10 / \mathrm{ml}$.

Table 3. Effect of phosphate on counts of Bact. coli on bile salts lactose agar

\begin{tabular}{|c|c|c|c|c|}
\hline \multirow[b]{2}{*}{ Culture } & & \multicolumn{3}{|c|}{ Bile salts lactose agar at $44^{\circ}$} \\
\hline & & \multirow[t]{2}{*}{ Medium A } & \multirow{2}{*}{ 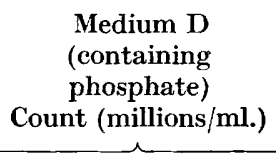 } & $\begin{array}{c}\text { Medium D } \\
\text { (without } \\
\text { phosphate) }\end{array}$ \\
\hline Strain & Age & & & $\rightarrow$ \\
\hline H 8 & $\begin{array}{l}6 \mathrm{hr} . \\
6 \text { days }\end{array}$ & $\begin{array}{l}530 \\
1.52\end{array}$ & $\begin{array}{l}11 \\
<0.01\end{array}$ & $\begin{array}{l}700 \\
1 \cdot 69\end{array}$ \\
\hline H 0 & $\begin{array}{l}6 \mathrm{hr} \text {. } \\
6 \text { days }\end{array}$ & $\begin{array}{l}430 \\
5 \cdot 8\end{array}$ & $\begin{array}{l}380 \\
0 \cdot 5\end{array}$ & $\begin{array}{l}490 \\
7 \cdot 3\end{array}$ \\
\hline H 7 & $\begin{array}{l}6 \text { hr. } \\
6 \text { days }\end{array}$ & $\begin{array}{r}180 \\
56\end{array}$ & $\begin{array}{l}99 \\
10\end{array}$ & $\begin{array}{r}316 \\
71\end{array}$ \\
\hline H 1 & $\begin{array}{l}6 \text { hr. } \\
6 \text { days }\end{array}$ & $\begin{array}{r}153 \\
60\end{array}$ & $\begin{array}{c}62 \\
9 \cdot 3\end{array}$ & $\begin{array}{r}219 \\
92\end{array}$ \\
\hline H 73 & $\begin{array}{l}6 \text { hr. } \\
6 \text { days }\end{array}$ & $\begin{array}{r}169 \\
22\end{array}$ & $\begin{array}{l}80 \\
1 \cdot 0\end{array}$ & $\begin{array}{r}196 \\
25\end{array}$ \\
\hline H 6 & $\begin{array}{l}6 \mathrm{hr} . \\
6 \text { days }\end{array}$ & $\begin{array}{r}154 \\
40\end{array}$ & $\begin{array}{l}\text { c. } 3 \\
\text { c. } 3 \cdot 5\end{array}$ & $\begin{array}{r}172 \\
38\end{array}$ \\
\hline
\end{tabular}




\section{L. A. Allen, Sheila M. Pasley and Margaret S. F. Pierce}

Effect of suspension in water on proportion of total cells of Bact. coli able to grow on bile salts lactose agar

A dilute suspension of cells was obtained by adding a small quantity of a broth culture of Bact. coli to $\frac{1}{4}$-strength Ringer's solution $(0.0015 \mathrm{ml}$. culture/l.); this was incubated at $20^{\circ}$ and at intervals counts were made on nutrient agar at $37^{\circ}$, and on bile salts lactose agar (medium $A$ ) at $37^{\circ}$ and at $44^{\circ}$. This procedure was repeated with broth cultures of different ages. Counts on the bile salts medium were expressed as percentages of the corresponding counts on nutrient agar, it being assumed that this medium exerted no appreciable inhibitory effect at $37^{\circ}$. Results for broth cultures of different ages (Table 4) indicate that in general the longer the period of immersion in Ringer's solution the smaller was the proportion of the cell population able to grow on the bile salts medium. With a young culture immersed for $\mathbf{3} \mathrm{hr}$. or more the inhibitory effect was much more marked at $44^{\circ}$ than at $37^{\circ}$.

Table 4. Percentage of total population of Bact. coli able to grow on bile salts lactose agar at $37^{\circ}$ and at $44^{\circ}$ after different periods of immersion in $\frac{1}{4}$-strength Ringer's solution

\begin{tabular}{|c|c|c|c|c|c|c|c|c|}
\hline \multirow{4}{*}{$\begin{array}{c}\text { Period of } \\
\text { immersion } \\
\text { in Ringer's } \\
\text { solution } \\
\text { at } 20^{\circ} \\
(\text { br) }\end{array}$} & \multicolumn{8}{|c|}{ Age of broth culture (hr.) } \\
\hline & \multicolumn{2}{|c|}{$\begin{array}{l}17 \\
\text { Bile salts } \\
\text { lactose } \\
\text { agar at }\end{array}$} & \multicolumn{2}{|c|}{$\begin{array}{l}41 \\
\text { Bile salts } \\
\text { lactose } \\
\text { agar at }\end{array}$} & \multicolumn{2}{|c|}{$\begin{array}{c}65 \\
\text { Bile salts } \\
\text { lactose } \\
\text { agar at }\end{array}$} & \multicolumn{2}{|c|}{$\begin{array}{c}89 \\
\text { Bile salts } \\
\text { lactose } \\
\text { agar at }\end{array}$} \\
\hline & $37^{\circ}$ & $44^{\circ}$ & $37^{\circ}$ & $44^{\circ}$ & $37^{\circ}$ & $44^{\circ}$ & $37^{\circ}$ & $\mathbf{4 4}^{\circ}$ \\
\hline & & Count & as per & age of & se on & rient & at 37 & \\
\hline 0 & $77 \cdot 5$ & $66 \cdot 3$ & $82 \cdot 4$ & $97 \cdot 3$ & $52 \cdot 4$ & $50 \cdot 5$ & $57 \cdot 3$ & $48 \cdot 3$ \\
\hline 1 & $78 \cdot 4$ & $63 \cdot 7$ & $72 \cdot 5$ & $62 \cdot 5$ & $32 \cdot 6$ & $48 \cdot 4$ & $49 \cdot 0$ & $40 \cdot 6$ \\
\hline 2 & $63 \cdot 8$ & $40 \cdot 6$ & $50 \cdot 0$ & $54 \cdot 8$ & $17 \cdot 4$ & $8 \cdot 8$ & $53 \cdot 5$ & $53 \cdot 5$ \\
\hline 3 & $46 \cdot 3$ & $16 \cdot 3$ & $51 \cdot 9$ & $23 \cdot 3$ & $13 \cdot 8$ & $7 \cdot 5$ & $46 \cdot 9$ & $46 \cdot 0$ \\
\hline 6 & $15 \cdot 8$ & $5 \cdot 7$ & $13 \cdot 0$ & $5 \cdot 4$ & $38 \cdot 0$ & $25 \cdot 4$ & $27 \cdot 1$ & $21 \cdot 1$ \\
\hline 24 & - & - & $11 \cdot 0$ & $7 \cdot 8$ & - & - & $8 \cdot 9$ & $7 \cdot 8$ \\
\hline
\end{tabular}

In a similar experiment (Table 5) the effects of immersion in full-strength and in $\frac{1}{4}$-strength Ringer's solution were compared. By making counts on bile salts lactose agar and on a similar medium from which the bile salts had been omitted the relative effect of the bile salts and of the high temperature of incubation $\left(44^{\circ}\right)$ was assessed. The broth culture was $41 \mathrm{hr}$. old at the time of immersion. With cells immersed in the full-strength solution bile salts exerted no very marked effect, and $60 \%$ or more of the total population was able to grow at $44^{\circ}$. With cells immersed in the $\frac{1}{4}$-strength solution, on the other hand, only $25-45 \%$ of the total population of cells was able to proliferate at $44^{\circ}$, and of these on the average only half could tolerate bile salts. The relatively severe action of the more dilute liquid on the bacterial cells was also reflected in the rates of death in the two solutions, counts on nutrient agar at $37^{\circ}$ showing that at the end of the $24 \mathrm{hr}$. period the percentages of the original cells surviving were $1 \cdot 6$ in $\frac{1}{4}$-strength and $46 \cdot 7$ in full-strength Ringer solution. 
Experiments with a strain of Bact. coli in $0.003 \mathrm{M}$ phosphate buffer at $\mathrm{pH} \mathrm{6.0} \mathrm{showed} \mathrm{that} \mathrm{before} \mathrm{suspension} \mathrm{in} \mathrm{this} \mathrm{solution} 90-100 \%$ of cells were able to grow at $44^{\circ}$. After immersion for 7-12 days, however, only about onehalf, and after 24 days only about one-third, of the cells could proliferate at this temperature. The temperature of incubation $\left(44^{\circ}\right)$ and the presence of bile salts thus both tend to inhibit growth of cells of Bact. coli into colonies, and the effects are more pronounced with cells attenuated by prolonged immersion in water.

Table 5. Percentage of total population of Bact. coli able to grow on bile salts lactose agar at $\mathbf{4 4}^{\circ}$, and on a similar medium without bile salts, after different periods of immersion in Ringer's solution of two different strengths

\begin{tabular}{|c|c|c|c|c|}
\hline \multirow{6}{*}{$\begin{array}{l}\text { Period of } \\
\text { immersion } \\
\text { in Ringer's } \\
\text { solution } \\
\text { (hr.) }\end{array}$} & \multicolumn{4}{|c|}{ Ringer's solution used for immersion } \\
\hline & \multicolumn{2}{|c|}{ Full-strength } & \multicolumn{2}{|c|}{$\frac{1}{4}$-strength } \\
\hline & \multicolumn{4}{|c|}{ Lactose agar at $44^{\circ}$} \\
\hline & With & Without & With & Without \\
\hline & bile salts & bile salts & bile salts & bile salts \\
\hline & \multicolumn{4}{|c|}{ Counts as percentage of those on nutrient agar at $37^{\circ}$} \\
\hline 0 & $\mathbf{7 2 \cdot 0}$ & $72 \cdot 0$ & $80 \cdot 7$ & $79 \cdot 0$ \\
\hline 1 & $82 \cdot 0$ & $77 \cdot 4$ & $28 \cdot 3$ & $45 \cdot 1$ \\
\hline 2 & $69 \cdot 4$ & $83 \cdot 9$ & $10 \cdot 0$ & $\mathbf{2 5 \cdot 5}$ \\
\hline 3 & $51 \cdot 6$ & $69 \cdot 4$ & $16 \cdot 2$ & $30 \cdot 4$ \\
\hline 6 & $62 \cdot 3$ & $68 \cdot 8$ & $38 \cdot 6$ & $45 \cdot 5$ \\
\hline 12 & $60 \cdot 3$ & $58 \cdot 6$ & $12 \cdot 7$ & $24 \cdot 2$ \\
\hline 24 & $91 \cdot 4$ & $94 \cdot 3$ & $11 \cdot 1$ & $33 \cdot 3$ \\
\hline
\end{tabular}

Differences in inhibitory action of different brands of bile salts

Two batches ( $\mathrm{N}$ and $\mathrm{O}$ ) of bile salts lactose agar were prepared, both being made with brands of bile salts of high quality but marketed by two different firms. A suspension of Bact. coli was made in $0.003 \mathrm{~m}$ phosphate buffer at pH $6 \cdot 0$, and colony counts in triplicate were determined on each of the two media at intervals over a period of $\mathbf{5 2} \mathrm{hr}$. In sixteen such tests medium $\mathbf{O}$ invariably yielded a higher count than medium $\mathbf{N}$, the increases ranging from 25 to 100 , with an average of $66 \%$.

\section{Effect of 'resuscitation' on proportion of cells able to grow on bile salts lactose agar at $44^{\circ}$}

Tests were made to see whether cells attenuated by a period of suspension in water could be so resuscitated by preliminary incubation in a nutrient medium that they were subsequently more resistant to the inhibitory action of bile salts and to a high temperature of incubation. The general principle in these experiments was to prepare the bile salts medium in two portions: (i) a broth containing the peptone and the sugar, and (ii) an agar portion containing the bile salts, neutral red and agar. Each portion contained constituents at twice the final concentration required so that mixing resulted in a medium of normal constitution. The inoculum was added to the broth, 


\section{L. A. Allen, Sheila M. Pasley and Margaret S. F. Pierce}

which was incubated for a period at $37^{\circ}$ before adding to the agar portion of the medium and preparing the film in the bottle.

For preliminary resuscitation the following two sugar broths were compared (constituents as g./l.) broth $\mathrm{E}$ : peptone, 40; sodium chloride, 10; lactose, 10; broth F: peptone, 15; Yeastrel, 6; glucose, 10. A $45 \mathrm{hr}$. broth culture of Bact. coli was suspended in $0.003 \mathrm{M}$-phosphate buffer at $\mathrm{pH} 6.0$ (4 parts culture to 1 million parts buffer). This suspension was incubated at $20^{\circ}$, and at intervals samples were removed and treated as follows: $20 \mathrm{ml}$. volumes of suspension were added to $50 \mathrm{ml}$. broths $\mathrm{E}$ and $\mathrm{F}$, and the mixtures were incubated at $37^{\circ}$

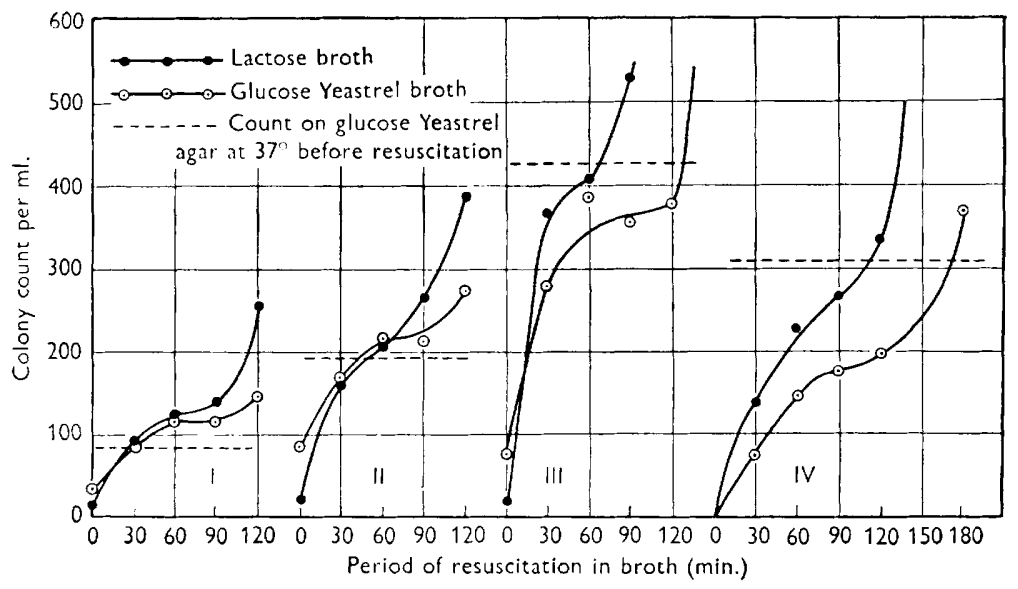

Fig. 2. Colony counts on corresponding bile salt agar medium at $45^{\circ}$ of Bact. coli after period of suspension in $0.003 \mathrm{M}$-phosphate buffer followed by different periods of resuscitation in $(a)$ lactose broth, $(b)$ glucose Yeastrel broth. (After suspension in buffer: I, for $24 \mathrm{hr}$.; II, for $48 \mathrm{hr}$; III, for $96 \mathrm{hr}$.: IV, for $125 \mathrm{hr}$.)

in a water-bath. At intervals of $30 \mathrm{~min} ., 3.5 \mathrm{ml}$. of each mixture were added separately to small culture bottles containing $2.5 \mathrm{ml}$. of the agar portion of the medium (consisting of $3.0 \%$ New Zealand agar, $0.3 \%$ bile salts ' $X$ ', and $0.02 \%$ neutral red) and colony counts were made in the usual way.

Counts in the two bile salts media after different periods of resuscitation are shown in Fig. 2. In each case it appears that two effects are superimposed, resulting in a sigmoid curve. It seems likely that these two effects comprise (a) a preliminary period in which increasing numbers of attenuated cells become 'rejuvenated' and are able to grow on the bile salts medium, and (b) a period when cells which have been incubating in lactose broth or glucose Yeastrel broth come to the end of the lag period and start to proliferate. Tests showed that no appreciable growth occurred in the glucose Yeastrel broth during the first $1 \frac{1}{2}-2 \mathrm{hr}$. of incubation. The two effects-resuscitation and proliferation-are, however, more distinctly separated in the glucose Yeastrel medium than in the lactose medium, suggesting that in the latter growth of some cells takes place at a somewhat earlier stage, and before all the cells have been resuscitated. 
It appears from Fig. 2 that, for organisms immersed in dilute buffer for periods up to $96 \mathrm{hr}$., a count approximating to the count on glucose Yeastrel agar at $37^{\circ}$ may be obtained by incubating the organisms for $1 \mathrm{hr}$. in lactose broth before introducing the bile salt, neutral red and agar. For organisms immersed for $125 \mathrm{hr}$. the counts so obtained would be somewhat lower. The curves suggest, in fact, that with increasing periods of immersion in buffer a decreasing proportion of total cells is capable of being resuscitated before proliferation of some of the cells begins.

\section{Effect of neutral red on count}

It was found by trial that a concentration of $0.006 \%$ neutral red in the medium was sufficient to give easily visible red colonies after incubation. This concentration was therefore adopted in subsequent work. Tests with two samples of sewage and six samples of polluted river water, in which colony counts on bile salts lactose agar containing neutral red were compared with counts on a similar medium containing no neutral red, showed that the dye had no significant effect either on the direct count or on the count following resuscitation. Similar results were obtained with a mixture of five strains of Bact. coli suspended in dilute buffer solution and incubated at $20^{\circ}$ in the laboratory. With one of these strains, tested singly, however, there proved to be a marked effect when the culture had been attenuated by a prolonged period of immersion. In the presence of neutral red the direct colony count of this strain was sometimes only a fraction of the corresponding count in the absence of the dye. The process of resuscitation appeared to remove this sensitiveness for in the subsequent colony counts, the presence of neutral red made no significant difference.

\section{RESLLTS OF APPLYING METHODS TO SAMPLES OF RIVER WATER AND SEWAGE}

Direct colony counts and counts after preliminary resuscitation were determined (by the methods given in the Appendix) on sixty-five samples of polluted river water and sixteen samples of settled sewage. The Most Probable Numbers (M.P.N.) of Bact. coli were determined on the same samples by the usual dilution technique (primary incubation in bile salts lactose broth at $37^{\circ}$ being followed by subculture of positive tubes into a similar medium at $44^{\circ}$ ).

Analysis of the results for river water showed that the direct colony counts (average of duplicates) ranged from 9 to $402 \%$ with an average of $90 \%$ of the M.P.N. Colony counts after preliminary resuscitation ranged from 37 to $676 \%$ with an average of $177 \%$ of the M.P.N. The wide range in percentages of colony counts is largely explained by the error of the M.P.N.

Results for the sixteen samples of sewage showed that direct colony counts ranged from $2 \cdot 5$ to $344 \%$ with an average of $109 \%$ of the M.P.N. After preliminary resuscitation the counts ranged from 80 to $2700 \%$ with an average of $572 \%$ of the M.P.N. The greatly increased count after resuscitation suggests that a large proportion of the organisms in sewage are in a moribund condition incapable of growing directly on the bile salts medium. 


\section{L. A. Allen, Sheila M. Pasley and Margaret S. F. Pierce}

The increases in counts of water and sewage following resuscitation may be compared with the results of experiments with pure cultures. From Tables 4 and 5 it appears that if, after immersion in water, all cells could have been successfully resuscitated, the counts on bile salts lactose agar at $44^{\circ}$ would have been increased by amounts ranging from 118 to $1233 \%$. In the experiments referred to in Fig. 2, resuscitation increased the counts of cells immersed for 24-96 hr. by $900-2040 \%$; none of the cells immersed for $125 \mathrm{hr}$. was capable of growth on the bile salts medium at $44^{\circ}$ without previous resuscitation.

\section{Specificity of colony count for faecal coli}

Fifty-four colonies (sixteen from 'direct' counts and thirty-eight from counts after resuscitation) were isolated from fourteen samples of water and two samples of sewage, and the resulting cultures were submitted, without purification, to the indol, MR, VP, and citrate tests. Forty-seven strains gave the correct reactions for Bact. coli type I, six further strains conformed to type except for slight growth in citrate medium, and one strain appeared to be a $44^{\circ}$-positive variant of Bact. aerogenes. The colony counts therefore appeared to be reasonably specific for faecal coli.

This paper is published by permission of the Department of Scientific and Industrial Research.

\section{APPENDIX \\ Methods of making colony counts \\ Direct colony counts}

(1) Agar medium: peptone, 20 g.; $\mathrm{NaCl}, 5$ g.; bile salts, ${ }^{*} 1.5$ g.; New Zealand agar, $15 \mathrm{~g}$; ; distilled water, $900 \mathrm{ml}$; pH value 7.0. (2) Lactose neutral red solution: lactose, $5 \mathrm{~g}$.; $0.6 \%$ neutral red, $10 \mathrm{ml}$; distilled water, $90 \mathrm{ml}$. Sterilization by autoclaving at $15 \mathrm{lb}$. for $20 \mathrm{~min}$.

Just before use $10 \mathrm{ml}$. of solution 2 are added to $90 \mathrm{ml}$. of the melted agar medium, and the mixture is maintained at about $48^{\circ}$. This is distributed in the culture bottles in quantities of $5 \mathrm{ml}$. and the bottles are maintained at the same temperature for a short time before adding the inoculum, $\dagger$ which consists of $1 \mathrm{ml}$. of a suitable dilution of the sample being examined. The bottles are rotated until the medium has set and are then incubated in a water-bath at $44^{\circ}$ for $24 \mathrm{hr}$.

\section{Colony counts after preliminary resuscitation}

(1) Double-strength broth: peptone, 40 g.; $\mathrm{NaCl}, 10 \mathrm{~g}$; d distilled water, $900 \mathrm{ml}$.; $\mathrm{pH}$ value, $\mathbf{7 \cdot 0}$. Fill into bottles in $90 \mathrm{ml}$. quantities and just before use add $10 \mathrm{ml}$. of $10 \%$ lactose solution which has been separately sterilized. (2) Double-strength agar medium: bile salts, 3.0 g.; New Zealand agar, 30 g.;

* The concentration of bile salts required depends on the purity and strength of the commercial article. Guidance can usually be obtained from the manufacturers.

$\dagger$ In larger bottles inocula up to $5 \mathrm{ml}$. were used. Quantities of agar medium and of lactose neutral red solution were increased proportionately. 
distilled water, $11 . ; \mathrm{pH}$ value, $7 \cdot 0$. Fill into bottles in $90 \mathrm{ml}$. quantities and just before use add $10 \mathrm{ml}$. of $0 \cdot 12 \%$ neutral red solution which has been separately sterilized.

Solution 1 is dispensed in $7.5 \mathrm{ml}$. quantities in $6 \times \frac{3}{4}$ in. test-tubes which are incubated in a water-bath at $37^{\circ}$. Inocula of $3 \mathrm{ml}$. of suitable dilutions of the sample being tested are added to separate tubes and the mixtures are allowed to remain at $37^{\circ}$ for $1 \mathrm{hr}$. Quantities of $3.5 \mathrm{ml}$. of this mixture (equivalent to $1 \mathrm{ml}$. of inoculum*) are then added to the small culture bottles to which $2.5 \mathrm{ml}$, of the agar medium have been added several minutes previously and which have been maintained at $48-50^{\circ}$. After rotating in the usual way the bottles are incubated in the $44^{\circ}$ water-bath for $24 \mathrm{hr}$.

\section{REFERENCES}

Allen, L. A., Brooks, E. \& Williams, I. L. (1949). Effect of treatment at the sewage works on the numbers and types of bacteria in sewage. J. Hyg., Camb. 47, 303.

BatтY-Sмith, C. G. (1942). The Eijkman test for faecal coli in the bacteriological examination of water supplies. J. Hyg., Camb. 42, 55.

ClegG, L. F. L. \& Sherwood, H. P. (1939). Incubation at $44^{\circ} \mathrm{C}$. as a test for faecal coli. J. Hyg., Camb. 39, 361.

CleGg, L. F. L. \& Sherwood, H. P. (1947). The bacteriological examination of molluscan shellfish. J. Hyg., Camb. 45, 504.

Hajna, A. A. \& Perry, C. A. (1943). Comparative study of presumptive and confirmative media for bacteria of the coliform group and for faecal streptococci. Amer. J. publ. Hlth, 33, 550.

Halvorson, H. O. \& Ziegler, N. R. (1933). Application of statistics to problems in bacteriology. III. A consideration of the accuracy of dilution data obtained by using several dilutions. J. Bact. 26, 559 .

Leirson, E. (1935). New culture media based on sodium deoxycholate for the isolation of intestinal pathogens and for the enumeration of colon bacilli in milk and water. J. Path. Bact. 40, 581.

Mrnistry of Health (1939). The bacteriological examination of water supplies. Rep. publ. Hlth med. Subj., Lond., no. 71. London: H.M. Stationery Office.

Proom, H. \& Hemmons, L. M. (1949). The drying and preservation of bacterial cultures. J. gen. Microbiol. $3,7$.

Sherwood, H. P. \& Clegg, L. F. L. (1942). Further studies of incubation at $44^{\circ} \mathrm{C}$. as a test for 'faecal coli'. J. Hyg., Camb. 42, 45.

TaI, T. Y. \& Van Heyningen, W. E. (1950). An easy method for counting bacterial colonies in roll tubes. Brit. J. exp. Path. 31, 155.

TAYLOR, C. B. (1945). The effect of temperature of incubation on the results of tests for differentiating species of coliform bacteria. J. Hyg., Camb. 44, 109.

Wilson, G. S., Twigg, R. S., Wright, R. C., Hendry, C. B., Cowell, M. P. \& MaIr, I. (1935). The bacteriological grading of milk. Spec. Rep. Ser. med. Res. Coun., Lond. no. 206.

* In larger bottles inocula up to $5 \mathrm{ml}$. were used. Quantities of broth and of agar medium were increased proportionately.

(Received 22 March 1952) 